\title{
Embodied Religious Belief: The Experience of Syahadatain Sufi Order in Indonesia
}

\author{
Masmuni Mahatma ${ }^{1 *}$, Zarrina Saari ${ }^{2}$ \\ 1 Departement of Aqidah and Islamic Philosophy, Faculty of Ushuludin UIN Sunan Gunung Djati Bandung, \\ Indonesia; e-mail: masmuni@uinsgd.ac.id \\ 2 Department of Akidah and Islamic Thought, Academy of Islamic Studies, University of Malaya, Malaysia; e- \\ mail: zarrina@um.edu.my \\ * Correspondence
}

Received: 2021-05-22; Accepted: 2021-06-25; Published: 2021-08-21

\begin{abstract}
Several types of research on religion in Indonesia emphasise more on religious knowledge and belief and less on other approaches such as material aspects. Religion is always related to material aspects such as mosque buildings, veils or robes for prayer, or holy water obtained from grave visitors. This study uses embodiment approach and material theory of religion to the imposition of special fashion in prayer that gives consequences on awareness and attitude of a new morality in-group cohesion. This study is a case study through participatory observations and interviews of new members of Syahadatain congregation, Cirebon, Indonesia for three years. The result of the study shows two significant findings namely first, the establishment of rituals through special fashions exerts an influence on discursive awareness and moral behaviour; and second, the driving factor of the emergence of new moral behaviour from the practice is the social gaze. This study recommends the need for the study of material artifacts such as clothing can be an alternative to the study of religion in Indonesia using the embodiment approach.
\end{abstract}

Keywords: Embodiment; fashion; moral; ritual; Syahadatain.

Abstrak: Penelitian mengenai agama di Indonesia selama ini menekankan aspek pengetahuan dan keyakinan seraya mengabaikan pendekatan lain seperti aspek material. Agama, sebenarnya, tak pernah lepas dari aspek material, seperti bangunan mesjid, kerudung atau jubah untuk shalat, atau air suci hasil dari ziarah kubur. Studi ini, dengan teori agama material, menunjukkan pendekatan penubuhan (embodiment) dalam penelitian Agama, yakni pengenaan fashion khusus dalam shalat memiliki konsekuensi pada kesadaran dan sikap moralitas baru dalam kohesivitas kelompok. Dengan studi kasus melalui observasi dan wawancara parisipatoris tehadap anggota baru Jemaah Syahadatain, Cirebon, selama tiga tahun, studi ini menemukan dua temuan: pertama, penubuhan ritual melalui fashion khusus memberikan pengaruh pada kesadaran diskursif dan perilaku moral; dan kedua, faktor pendorong munculnya perilaku moral baru dari penubuhan adalah yakni tatapan mata sosial. Studi ini merekomendasikan perlunya pendekatan penubuhan (embodiment) dalam penelitian agama di Indonesia.

Kata Kunci: Mode; moral; penubuhan/manifestasi; ritual; Syahadatain.

\section{Introduction}

Modernity, to a certain extent, has made religious spirituality left behind and replaced it with philosophical reason, not only in understanding the world but also in understanding moral origins. Immanuel Kant, a philosopher who declared modern man's maturity in the sense that religious upbringing no longer needed, believed that moral action was guided by reason separated from embodiment, practical activity (Kant, 1993). Consequently, religion is often described as mental and 
spiritual and rarely it is viewed as material. It is seen as a subjective, private, and cognitive aspect, and only vaguely as a concrete thing that can be mediated or felt. The idealistic notion of religion relegates its material dimension to an epiphenomenal embellishment, as a weakened manifestation of belief. The primacy of faith continues to inspire much scientific and popular discourse despite many strong criticisms (Asad, 1993; Morgan, 2010; Vásquez, 2010). This criticism produces a study of "material religion" or "material religion and culture" which shows that religion does not only exist in thoughts and texts, but also the material world including the human body and its senses.

Several studies have shown the material aspects of religion. The study of the commodification of the Holy Land, sacred objects in Japanese Buddhism, new ritual practices in American Judaism, the materiality of semiotic forms in mission meetings in Sumba, Pueblo dances, mass-produced images of Jesus in Ghana, relations with the dead in Palo Cuba, media religion on Oprah's show, racist Jesus images in America, and Islamic visual culture (Elias, 2012; Meyer, 2011; Ochoa, 2010). Winchester (2008) conducted a similar study regarding iconic objects such as crosses, statues of holy figures to the formation of religious awareness. Winchester found a relationship between material objects and religious understanding of objects that iconically depict certain sacred figures. It is through discursive awareness that the users considered iconic objects as sacred figures which guide and supervise them (Winchester, 2008).

In line with Winchester's study, Bell's study (1992) shows the influence of ritual practices on daily behaviour after being mediated by the process of interpreting symbols. Therefore, fashion or material objects in rituals are only meaningful when they are understood symbolically and communicatively, not as technical and affective behaviour (Turner \& Asad, 1994). Other studies suggest that bodily ritual practices (such as prayer, and fasting) can change the moral disposition, or habitus, associated with being a moral human (Mahmood, 2012; Turner \& Asad, 1994; Winchester, 2008, 2017; Winchester \& Guhin, 2019). Cognitively, both studies above contrast the two consciousnesses namely discursive awareness through interpretation and non-discursive awareness through bodily practice even some sociologists have begun to reconcile (Brekhus, 2015; Cerulo, 2010; Ignatow, 2007; Vaisey, 2008, 2009).

However, such studies are still rarely found in religious research in Indonesia. Clifford Geertz (1973) had provided the initial capital for the study of this material religion. Geertz (1973, p. 91) has defined religion as a system of symbols that work in the way of language or text. As a symbol system, the practices and material objects of a religion-such as places of worship, dances, pilgrimages, and amulets - function as outward symbols that function as containers of inner religious meaning namely beliefs, values, attitudes, and ideas that underlie the cosmic order. Thus, material things embody other immaterial things such as beliefs and meanings which are considered the blueprints or true essence of religion. Appadurai (1986) and Scheper Hughes (2010) developed this Geertzian thought model. They argued that material things are "privileged signifiers." However, this research has not been found for the study of religion in Indonesia.

On that basis, this article presents fashion as a religious material at the congregation of the Syahadatain congregation in Cirebon, West Java, Indonesia. This congregation believes that the imposition of special fashion in prayer can encourage a deeper understanding and experience of religion. The Syahadatain is congregations of the Sufi order who preserve the teachings of Sunan Gunung Djati about the importance of continuously improving oneself through reading the two sentences of the creed, the profession of faith in Islam namely 1) There is no God but Allah; 2) Muhammad is the Prophet of God. One of the special characteristics known to the wider community is the wearing of special clothes for male congregations when carrying out prayers and Sufi order rituals. The special clothes are in the form of a turban robe, udeng-udeng white (a headband from a piece of cloth), and ridah (a white cloth wrapped around the neck), see figure 1. 


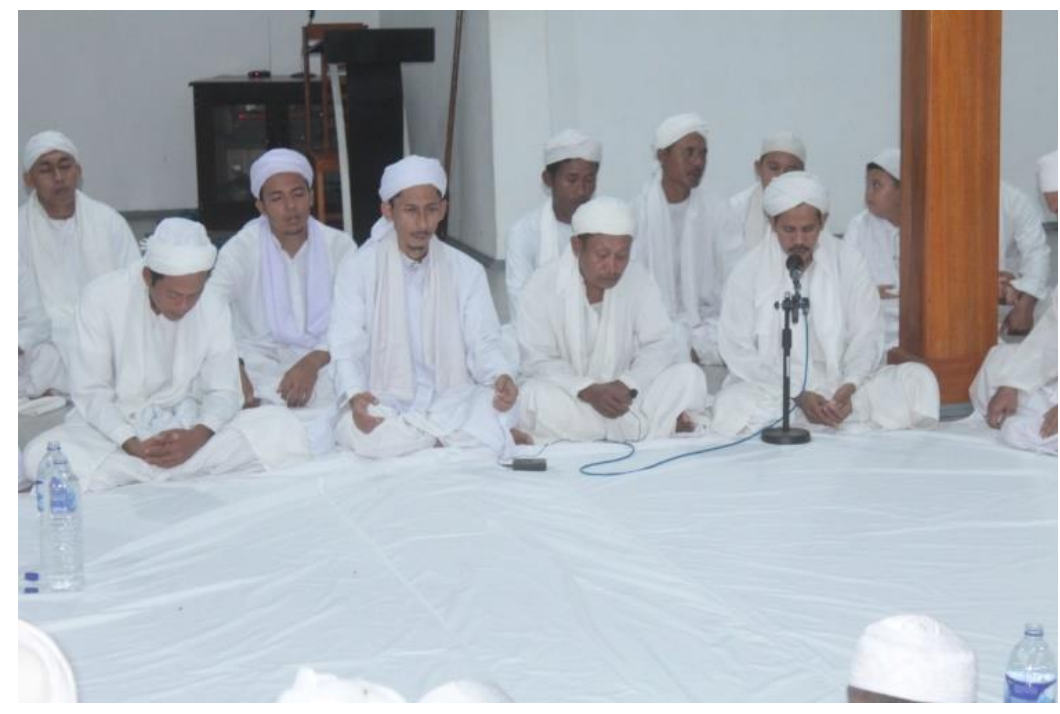

Figure 1 Special prayer clothes of Syahadatain congregants

The use of this special dress is quite ostentatious compared to the dressing habit in the prayer of other Muslims in Indonesia. In general, the dressing requirements in prayer are only clean from najis (impure, ritually unclean) and cover the aurat (the bodily part that is mandatory to be cover) between the navel and the knees without questioning the shape and colour of the clothes. Based on the records in the figh (Islamic jurisprudence) tradition, the dress codes in prayer are the prohibition of wearing prayer clothes with pictures (Al-'Asqalānī, 2005; Al-Hishni, 2001), wearing a head covering (Al-Bakri, 1997, p. 226), and free colour and type of clothing as long as it does not interfere with other congregational prayers. The wearing of special and white prayer clothes for the Syahadatain congregation creates an exclusive impression that reflects various public judgments such as being more pious, "pilgrims" (not yet performing hajj but claiming to have performed, exaggerating, or being too Arabist.

For this reason, this article will focus on three questions: (a) What is the position of the white turban in the Syahadatain congregation in Cirebon; (b) What are the factors that cause the wearing of a white turban in congregational prayers in the community, and (c) How is the imposition of a white turban specifically in congregational prayers affect the moral behaviour of the performer.

The turban as a special garment, in this article, is seen as the embodiment of a material object. The special fashion in the prayer ritual is a typical material object that is used and then responded to and associated with the concept of religious teachings based on embodied bodily experiences or perceptions. The special fashion for prayer in this study is positioned as an embodied metaphor so that it becomes the centre of both discursive and non-discursive (practical or habitus) awareness activities. On the other hand, because it is related to the habitable ritual, the special white-and-white fashion becomes the centre point of habituation that produces certain awareness including a new moral disposition. To explain this process, this article uses several theories of material religion and social body proposed by David Morgan (2009, p. 16). He states:

... religions are not essentially ideational, conceptual, or volitional. They are all of these, of course, but they also exhibit the corporeal nature of human existence, which means that religions consist of feeling, sensation, implements, spaces, images, clothing, food, and all manner of bodily practices regarding such things as prayer, purification, ritual eating, corporate worship, private study, pilgrimage, and so forth.

Based on this perspective, the special dress for prayer on the Syahadatain congregation is the point, not the path to the essence. Morgan states "should we say that the 'essence' of religion is what people say in prayer or worship?" if so, material things are mere epiphenomena, fringe decorations that are not important. The existence of material things such as umrah clothes in hajj cannot be replaced either in form or colour. 
This article examines material aspects of religion and spirituality. The main question is whether material objects only occupy an epiphenomenal position for the practice of Islamic spirituality. Another question is how material objects such as clothes in prayer can be the essence of spirituality which is apart from material things. This study uses a qualitative research design with an ethnographic perspective. The main point lies in the effort to describe factually, actual, natural, emic, and holistically about the special clothes for prayer in spirituality. In this study, researchers live together to 'observe and listen' to the practice of the Syahadatain. The researchers then found that there are prayer clothes, such material things, that have an important position in the overall practice of the Syahadatain in Cirebon, West Java, Indonesia. Therefore, to find the relationship of material objects in the overall practice of spirituality, this article employs observations and interviews with the new members in the Syahadatain congregation.

\section{Material Culture in Religious Studies}

The study of material religion is still rarely conducted although it has an undeniable logic that every religion uses certain material objects. Therefore, Engelke (2011) states 'all religion is material religion.' It is a statement based on the fact that religious traditions always articulate the boundaries and relationships between immanence and transcendence (Lambek, 2014, p. 16). Although it is still problematic, material religion expands religious research into the area of objects that are not previously considered important. Asad (2001) identifies "religion - whether musical, pictorial, or textual - the materiality of religion is integral to its constitution. In line with him, Latour confirms that what is meant 'something' (things) in material religion is clearer. He said 'religion...does not speak of things, but from things', a category that includes 'entities, agencies, situations, substances, relations, experiences, whatever is the word' (Latour, 2010, p. 101). Therefore, this article does not talk about the prayer clothes of the Syahadatain congregation and then suggests the underlying beliefs, but "from things" such as fashion, a network of possible meanings from religion are revealed.

Sonia Hazard (2013) suggests three approaches to the study of religious material: material practice as a symbol, the relation of material practice to power, and material phenomenology. The first approach views material things and practices as symbols that must be interpreted for the religious meanings they carry. It refers to the Geertzian tradition as did Appadurai (1986) and Scheper Hughes (2010). The second approach emphasises the role of material discipline in the formation of religion through material practice. It refers to the Foucauldian tradition as in the study of Asad (1983) and Mahmood (2012). The third approach, referring to the phenomenological tradition, pays attention to the role of material objects that are influenced by human experience and cognition, as did David Morgan (2010), and Promey and Brisman (2010).

The turban in the Syahadatain Sufi order in this article is a networked material object as stated by Morgan. For Morgan (2010), "material culture is not just objects, not just architectural foundations or jewellery or paintings", because material objects in religion have values that go beyond their material things ("things are more than things"). Objects in religion are even considered as "networks" and "the stage on which a social actor, a person, a human being takes her place" (Morgan, 2010).

'Material culture', for Morgan, consists of two aspects, namely 'the material things that people use and value' and 'the practices, places, attitudes, and schemes of thought and value that shape their perception and valuation of the things' (Morgan, 2009). In this study, special clothes for prayer are the material things that are used and have value. It forms certain perceptions and experiences for users. The Syahadatain congregation not only has cultured special clothes which are material objects but also has spread the use of it in the tradition culturally.

Then, Morgan emphasised that embodiment is the 'principal register for religion'. Without embodiment, researchers fail to understand one of the most powerful aspects of religious behaviour. Religion, therefore, operates on and consists of material things, make and made by the body. Religion shapes its adherents through the body, not as a separate external party. Furthermore, Morgan believes that material religion presents what is imagined to be experienced as well as presents the sensation of oneself as part of a social body. 


\section{Fashion and the Establishment of Religious Awareness}

The focus of the material object of this article is special clothing for prayers and rituals, namely a white robe completes with a headband and ridah. Studies on fashion and the body, although not so dominant, have been carried out by several researchers such as Entwistle (Entwistle, 2000, 2015); Negrin (2016); and Woodward (2007) which relates the sensual, affective, and experience of dressing. The prominent among this literature is Entwistle's article which discusses fashion as 'a situated bodily practice' (Entwistle, 2000, 2015). Her article synthesises insights into Merleau-Ponty's (1962) corporeal phenomenology, Maus' (1973), and Foucault's structuralism (Foucault, 1975, 1977, 1980) with Goffman's (1971) and Bourdieu's work on practice and habitus (Bourdieu, 1990). Entwistle (2001) explains that the practice of the body besides being shaped by culture is also shaped by daily practice (dressing). Entwistle develops a theoretical position that recognises the limitations of poststructuralism regarding fashion while aiming to integrate the living experience of the body. A key insight from Entwistle's work is to recognise the importance of the movements, actions, and behaviours of the body dressed as being shaped by the social forces acting on it. These actions and movements consist of "technique" and "practice of dressing". Similarly, research by Nuroniyah (2019) about the use of a specific branding of hijab (veil) shows that the 'practice of dressing' does not only function to cover the nakedness and body, but also aesthetic value and luxury.

In this article, the use of a white turban in congregational prayers is positioned as a "practice of dressing" that forms the body of the congregation of the Sufi order. The provision is only to wear special clothes when carrying out prayers and Sufi order rituals. Meanwhile, people can wear clothes in general outside these two activities. People create a life experience from a distinctive body. The clothes worn when performing rituals and prayers give them specialness, while there is no specialty in their ordinary life. There is a change between "we" (in this specific community) and "we" (in society) which is experienced through kinesthetics experiences and bodily touch. One experience presented by Lewellyn Negrin (Negrin, 2012a, 2012b, 2016) is about the experience of dressing.

Another theory related to clothing is Rudolf Laban's theory of body movement. According to Laban (1980, p. 68), "each phase of the movement, every transference of weight, every single gesture of any part of the body, reveals some features of our inner life"- "every phase of the movement, every transfer of weight, every movement of any part of the body, reveals some feature of our inner life" (Laban, 1980, p. 19). The clothes worn affect the movement of the body. The clothes are not just a wrap of the body but order certain movements.

This article examines clothing, movement, and body from a phenomenological perspective. Clothing and motion are associated with our practical involvement in the world. Based on the perspective of Merleau-Ponty's physical phenomenology $(1962$, p. 5), the body and its immersion in the world are the centres of human embodiment, because "the body forms our point of view upon the world". Thus, the clothing and movement, as well as the actions of the Syahadatain congregation are understood as the way humans mediate their environment.

\section{Contestation of the Syahadatain Congregation in Cirebon, West Java, Indonesia}

The Syahadatain congregation is a Sufi order group that grew up in Cirebon. It began to show its existence in the 1970s. Although they claim that the teachings of this Sufi order originated from Sunan Gunung Djati (1448-1470), one of the guardians who spread Islam in West Java, the main character was Sayyid Umar bin Ismail bin Yahya. The congregation called him Syaikhunal Mukarom (honourable figure). He died in 1973. Sayyid Umar had developed the Syahadatain congregation since 1923 and continued to develop rapidly to various provinces in Indonesia either socially or politically (Mastuki \& El-Saha, 2003, p. 237). The leaders of the Syahadatain congregation were affiliated with the Masjumi Party during the Old Order. Whereas during the New Order era, Sayyid Umar was directed to become Golkar supporters in 1971. It was against the current political trend of Muslims in Cirebon who affiliated with Partai Persatuan Pembangunan (PPP or the United Development Party) at that time. The decision to support Golkar was accommodated at both the national and regional levels. At the national 
level was the presence of a representative from the Syahadatain as a group representative in the MPR RI namely HA Ismail bin Umar (1973-1982), then continued by Idris from Kuningan, West Java. Meanwhile, at the regional level, the leaders of the Syahadatain namely A. Ahmad Yahya and Ayip Abdurrahman support the decision at the Cirebon Regency DPRD FKP (Nurchozim, Personal Communication, July 13, 2020).

Syahadatain Sufi order was once considered heresy because it was prohibited in the 1960s. It could reopen based on the Cirebon Resident's decision Number: 319/Pol.9/1963 on July 17, 1963 (Nurchozim, Personal Communication, July 13, 2020). Then, especially after supporting the New Order in 1971, the Syahadatain congregation grew rapidly and even had branches in 14 provinces in Indonesia.

In the public space, people cannot recognise the whereabouts of members of the Syahadatain congregation. The clothes are the same as those of the general public. There are no special characteristics in dressing in public spaces, such as isbal pants (trousers that the lower border is above the ankles), wearing robes, or wearing a turban just like the Tabligh congregation. The leaders of the Syahadatain congregation also do not wear turban robes in their daily lives. They appear like Kyai or clerics in general in Indonesia.

In Cirebon, the presence of the Syahadatain congregation is more recognisable every Friday night, especially on Kliwon Friday Night (referred to Javanese calendar). Since the afternoon, there has been a lot of mobility of people from the area around Cirebon such as Indramayu, Kuningan, Brebes, Bandung, and others. People from those areas come to Panguragan village to carry out Marhabaan (recitation of Maulud Barjanzi, special prayers) in the congregation. The Panguragan Mosque as the centre of Syahadatain is full of worshipers wearing white robes. Especially so on Kliwon Friday night, they fulfil the football field in front of the mosque.

During this congregation, around the mosque, many sellers sell white clothes and perfume. Usually, the merchants of turban robes are Kyai's family or it is from Islamic boarding schools affiliated with Syahadatain. Outside the mosque, at the square, and on the streets, people around Panguragan village are jostling for shopping at this "temporary market" every 40 days. While Syahadatain congregation had been wearing their white clothes praying together, praising the beauty of the behaviour of the Prophet Muhammad, other people were walking and shopping along the road for about three Kilometres.

In the field, the congregation in white clothes had begun to sit in an orderly manner while chanting prayers following the other congregations who were circling in the mosque. The prayers recitations were in Arabic and Javanese-Cirebon in turn with a certain tone. The streets were crowded by the general public who want to buy food, clothes, or just take their children to buy toys. The sound of $d h i k r$ resounded and grew louder as they approached the mosque. All of them echoing in the same tone as they were all wearing white clothes. At the time of $d h i k r$ together, there was a sound of replying to each other. There was also a time when they stood with their hands raised, even pranced in white clothes.

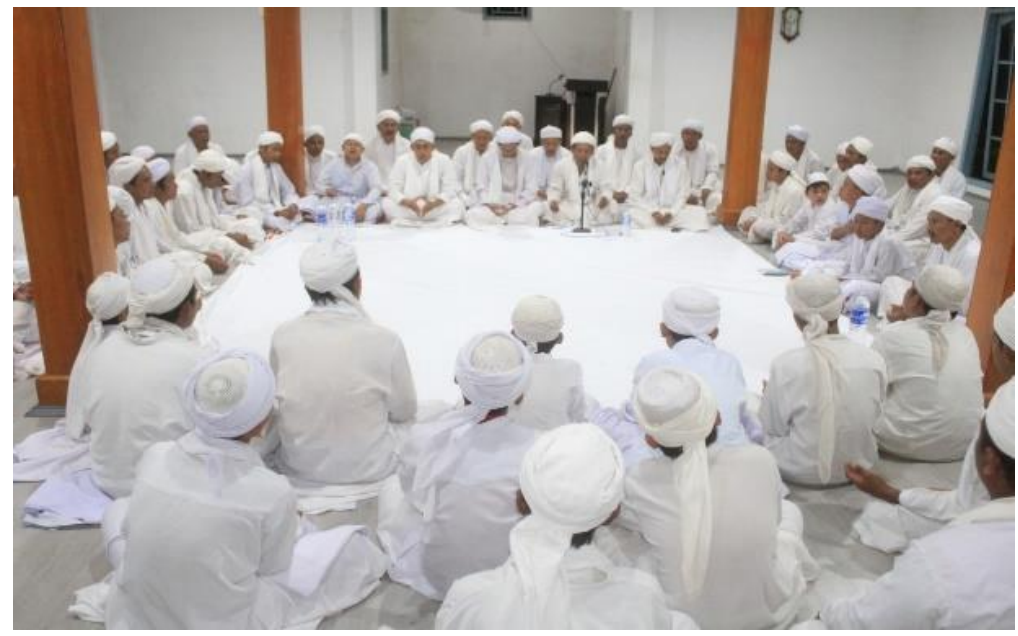

Figure 2 Syahadatain congregation gathering in the mosque 


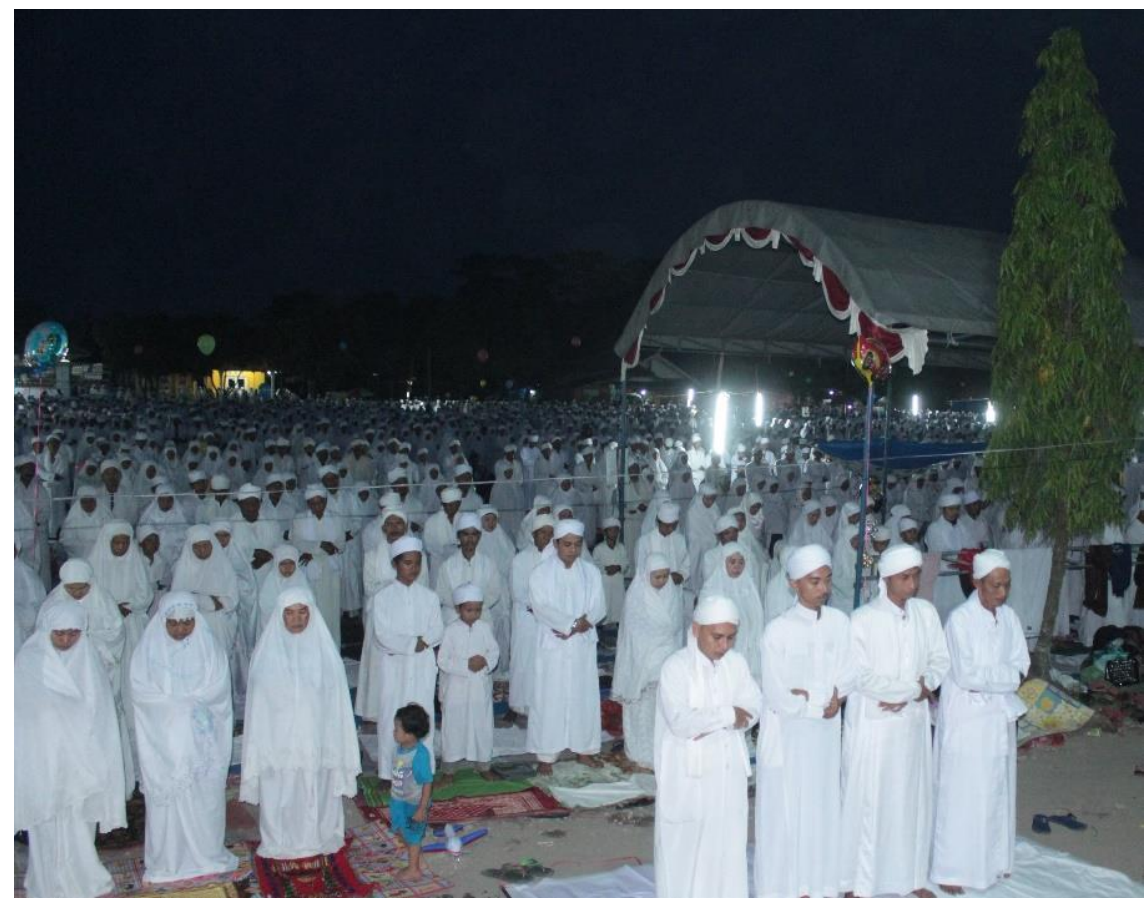

Figure 3 Congregants outside the mosque light up the night with their prayer white clothes

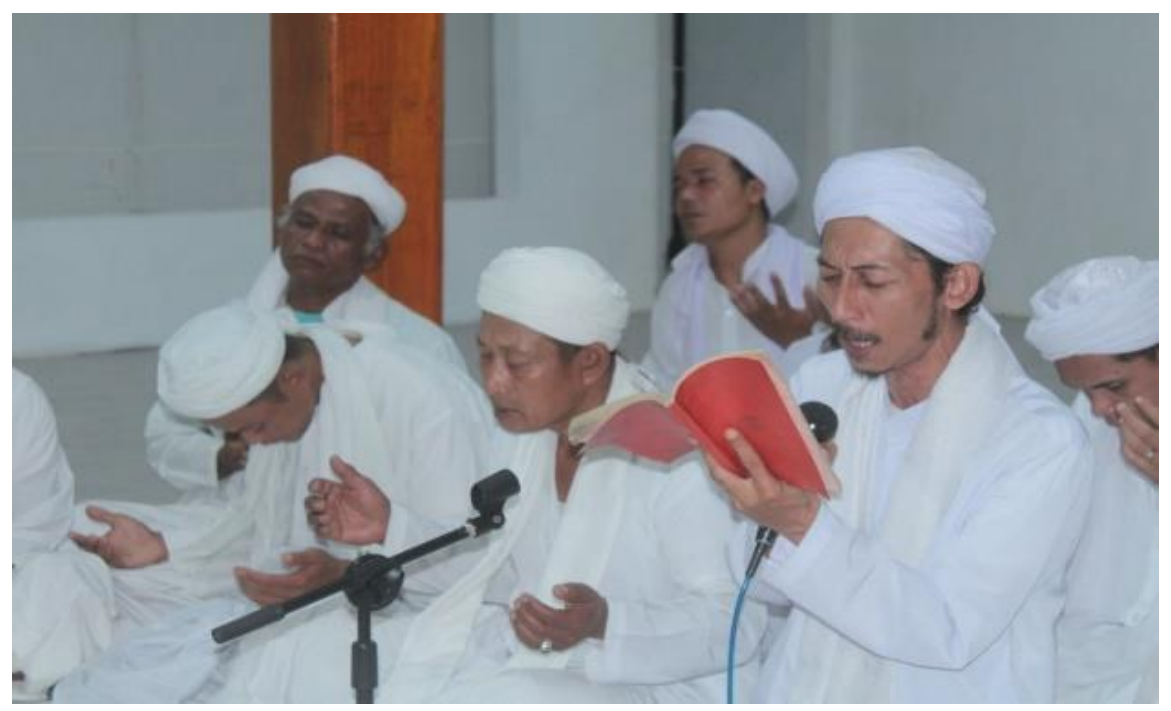

Figure 4 Chanting the prayers

Congregants dressed in white filled the mosque and the field outside the mosque (figure 2). It turned the dark colour of the night into white (figure 3). The voices of prayer were heard getting deeper, containing prayers and praises, "awak bodo hormatana kanjeng Nabine, mugi angsal amal soleh ning atine (stupid self, respect the Prophet Muhammad, hopefully, it will reach pious deeds in this heart). This Cirebon Javanese-language prayer calls on oneself to respect and obey the Prophet Muhammad so that all actions derive from a heart full of love for the Prophet (figure 4).

\section{Spirituality Embodiment Through Special Clothing}

Sayyid Gamal Yahya, the 3rd leader of the Syahadatain congregation after Sayyid Umar bin Yahya, said "Get him a turban robe!" pointed to a member of Syahadatain who brought his guest friend. "If you want to come to pray with us, wear this white turban robe." Then, the guest wore the robe and put the headband on. Sayyid Gamal further stated, "The end of the headband must be on the right side because we are Muslims, not behind like polytheists or on the left like hypocrites" (Personal Communication, 
December 23, 2020). The first thing experienced by someone who enters the Syahadatain congregation is wearing a white turban robe. Teachings and understanding are not the first time given. The disciplined practice of wearing white clothes during prayer is the entry point.

This local Sufi order encourages its congregation to study the two sentences of creed (the confession of faith - Syahadatain) as the core of self-improvement. It seems to be the origin of the name Syahadatain congregation, a religious group that follows the two sentences of the Shahada. For them, faith is to follow and make Allah the only God and Muhammad the Messenger of Allah. Prayer, as the embodiment of the two sentences of the creed, must put Allah first. "It's like facing the king that needs special clothes. Prayer is a ritual to face the king that needs the best clothes which are loved by the king," said Kyai Nurchozim, one of the leaders of the Syahadatain congregation (Personal Communication, July 13, 2020). So, when someone initiates to become a member of this Sufi order, he must imitate the behavior of the Prophet Muhammad by training himself to wear white clothes in every five daily prayers and Sunnah prayers.

Some of the new members of the Syahadatain congregation have embraced Islam since birth or of Islamic descent. However, they want to enter Islam more fully (kaffah). Islam as a religion in Indonesia is adopted automatically (without any initiation process such as baptism) by most children from Muslim families. According to Andi, this religion makes them unaware of the meaning of the ritual, "everything is just done out of habit" (Personal Communication, November 20, 2020).

In fact, I was a bit disappointed when I was only asked to wear white clothes, I wanted a way of religion that was more profound, full of understanding and appreciation, not just dressed differently (Andi, Personal Communication, November 20, 2020).

Then, he tried to wear white clothes every time he prays at home. Several times he wears and when he prays in the mosque. He said:

It was not easy. There is a sense of shame and reluctance when wearing white clothes in the mosque. The neighbours looked at me curiously. I could hear whispering among them. Some are sneering, some are smiling because they find it funny. Moreover, when I was in the mosque, some people immediately looked at me differently... (Andi, Personal Communication, November 20, 2020).

The Indonesian society relates white robes and turbans to the identity of great Kyai, even Wali (as in the Wali Songo films). It means that they are identical with the possession of religious knowledge and normative piety above average. This public assessment made the new congregations receive special treatment when praying in the mosque, "There are people who have excessive respect, I was suddenly asked to be the imam of prayer, even though I can't do anything. I was also asked to lead the prayer. They associate robes and turbans as clothes for sheiks, rulers of high knowledge and pious behaviour...," said Ahmad (Personal Communication, December 11, 2020).

This public assessment made some new adherents make them avoid going to the mosque in white clothes as Andi and Ahmad did. Others feel that they have a new responsibility. "There is a choice whether to stop wearing white clothes when praying or equip yourself with the appropriate knowledge and charity ..." said Didi (Personal Communication, December 11, 2020) telling his initial experience of wearing a white turban. Ahmad recounted his experience, "If you want to be ummah of the Prophet, one way is to carry out the sunnah... that is to wear this robe, as ordered by Mursyid (a spiritual guide) Syahadatain. At first, it was difficult because wearing special clothes for men's prayers was uncommon. Then, I saw my wife and daughter who had to wear a mukena (a special clothes prayer for Indonesian Muslim women) for every prayer. Then, the conversation appears in my mind, do only women can do it? If my wife and my daughter can do it, so do I ..." Then, Ahmad expressed the sensation of wearing the special fashion. He said, "I feel calmer... at least I am aware that I am praying" (Personal Communication, December 11, 2020).

Special clothing in prayer provides an experience of ritual as a time of rest. Prayers in Islamic teachings take place five times a day. The time of execution is spread amid the busyness of life (morning, mid-afternoon, late afternoon, late evening, and evening). The implementation of prayer, 
with this spread of time, can be arranged amid busy work at the office, on the way, or during rest and sleep. The implementation of prayer itself is very short, only about 5 minutes. But its existence amid busy life activities can be an obstacle to the busyness of modern society. Therefore, the prayer is carried out quickly, "just do it", and without reflection.

This special prayer dress makes me feel the time off amid busyness. Just imagine, usually, prayer activities can be done so quickly. Now, everything has to be done slowly. Starting from stripping clothes, putting them on, then putting on a robe and sarong, tying a turban, and tidying it up. Moreover, using fragrances is also sunnah in prayer. Everything I do is like a preparatory ritual before praying," said Agus (Personal Communication, December 11, 2020).

Meanwhile, Didi stated, "At first, it was annoying. But over time, I felt prayer as a time that released me from busy work..." (Personal Communication, December 11, 2020).

The Syahadatain Cirebon congregation considers wearing a white robe and white turban which is wrapped around the head as an inseparable obligation of the implementation of prayer. Without the special clothes, the implementation of prayer is considered imperfect. It is based on the belief that the Messenger of Allah wore and ordered the use of white clothes for prayer and also for wrapping the corpse, "Indeed, white clothes are the best clothes for you" (Hazim, 2016, p. 14).

The wearing of special clothes for prayer provides a break from the busyness of daily activities. "The obligation to wear white clothes in this prayer makes us rethink, reflect on the meaning of Islam." Specifically, the white fashion worn creates a preparatory ritual. "Every time you want to pray, there is an intention that must be prepared, not only in intentions but also in dressing," Didi recounted his experience (Personal Communication, December 11, 2020). Ahmad put forward another analogy, "I feel like I want to perform on a theatre stage or other performances. I can't wear a daily costume. I have to wear a special costume based on the role I'm going to play. Once the costume was put on, I was ready with a new role, new dialogue, and new behaviour that was different from the previous situation. All of this cause its preoccupation" (Personal Communication, December 11, 2020).

Special clothing for prayer makes prayer an important ritual for these new practitioners. "Wearing a turban robe takes time. Unlike before, after ablution, immediately carry out prayers with clothes attached to the body. It makes me have to prepare additional time before prayer time. Before prayer time arrives, I am ready at least five minutes before" (Ahmad, Personal Communication, December 11, 2020).

On the other hand, the experience of wearing a turban in a mosque makes new practitioners of the Syahadatain announcing their difference. As Andi stated, all eyes looked with curiosity and suspicion. "I was like being exiled. I am no longer part of the congregation in my village mosque." Andi continues to fight this feeling because of his desire to explore Islam which is more than just a habit. "Even though I felt isolated at first, I felt comfortable in this outfit. The prayer that I have been doing for a long time has now become a special ritual... like a special meeting at a special time and a special dress" (Personal Communication, November 20, 2020).

"This robe makes me feel watched over and encourages me to maintain my daily behaviour", said Didi (Personal Communication, November 20, 2020). "I felt the need to be completely different from those who looked on with suspicious eyes. I am different because I am the Syahadatain congregation member. Therefore, I have to show new behaviour." The suspicious eye view, fortunately, did not last long, based on Ahmad's confession. "Perhaps because in everyday life I still dress like others and I behave and get along, as usual, the neighbours consider my prayer clothes, not as suspicious overtime" (Andi, Personal Communication, November 20, 2020).

After 40 days of wearing white clothes during prayer, the early practitioners of the Syahadatain congregation received the teaching of Syahadatain. For the leaders of Syahadatain, as revealed by Kyai Nurchozim, special clothes in prayer are an effort to revive the Sunnah.

Some choose to imitate the physical appearance of the Prophet such as maintaining a beard and dressing Arabic, some choose to exemplify the Prophet's social attitude in associating. We at the Syahadatain are self-conscious as people who have no power... We're stupid yet... but want to also live the sunnah. Our teacher set a simple thing in reviving the Sunnah: dressed in white during 
prayer... only during prayer, after which return with colourful daily clothes (Nurchozim, Personal Communication, July 13, 2020).

The overall white colour for the Syahadatain congregation is conditioning or a nonverbal prayer. "Like when making salted eggs, the salted mud is just the outside of the egg. But we know that the inside will be salty by itself", Kyai Nurchozim presents an analogy about conditioning through white clothing (Personal Communication, July 13, 2020). "A good and calm heart is intended, to be able to change the heart for good can start from good clothes. White clothing will make the heart white [clean]" (Nurchozim, Personal Communication, July 13, 2020). So, in the Syahadatain congregation mosques, every prayer time comes, there is a unique sight. Everyone dressed in white and wore a white headband. Even the prayer mats are white.

\section{From Clothing to Spirituality Body}

From a phenomenological perspective, this study examines clothing, motion, and the body. Due to the perspective of physical phenomenology, Merleau-Ponty (1962) believes that it provides a unique perspective on the world of life. As emphasised by Latour (2010), this research departs from "from things" namely special clothing for prayer in the Syahadatain congregation to reveal a network of possible meanings from religion. In other words, it is a distinctive view of the world. This research makes cultured material, special clothing for prayer at this case, as a starting point for the study of material culture as stated by Morgan (2009) that the study of material culture means "study of cultured or culturally conceived and deployed things."

This study makes the Syahadatain congregation beginners, as informants of the research, about special clothing for prayer as an entrance to experiencing spirituality. The teaching of Syahadatain congregation spirituality begins with the participation of the body through the wearing of special clothes during prayers and rituals such as tawassul (seeking closeness) and marhabaan (chanting special prayers rituals). Three aspects of analysis will be discussed. Those are the position of clothing as a material object in spirituality, the relation of special clothing in prayer with the formation of the social body, and the ability of special clothing in prayer to present transcendent things.

First, the beginners of the Syahadatain congregation get a spiritual awareness network from the special clothes. Special clothes for prayer encouraged them to deepen their religion. The absence of teaching or theory of spirituality for beginners makes special clothes for prayer a mediator of deepening spirituality. Teaching is not transferring the knowledge, but transferring experience which opens a new perspective on religion. At this point, they not only wear the clothes on their body but also the tradition of the Syahadatain spirituality and the individual with the divine. Prayer in special clothing is a material way of practicing religion as something that a person feels in his flesh and gestures.

Here, spirituality creates and is created by the body. Spirituality is not a separate social institution that works like a cultural factory to produce individuals. Spirituality is attached to the experience of the body. The congregation got the conclusions to enter deeper into the esoteric realm of religion through the body after experiencing the sensation of dress practice, not through forced doctrine. Special prayer clothes become a constructive operation of spirituality in human life. The practice of dressing specifically in prayer has a function as a constitutive of religion. Clothing organises the world of those who wear it into coherent domains of experience such as social order, personal relationships, and interactions with forces beyond the direct control of the body or community (Morgan, 2009). Because embodiment and materiality consist of a living religion that makes sensations and feelings as a medium of belief.

Second, this research reinforces bodily practice as stated by Entwistle (2000). Besides being shaped by culture, bodily practice is also shaped by daily practice such as dressing. In line with Entwistle, Laban (1980, p. 19) stated that the clothes worn affect the movement of the body. Therefore, the clothes are not just a wrapper of the body but also order certain movements and even certain awareness about themselves and their environment. 
The interesting information of this study is a distinctive social body for beginners when wearing special clothes. Morgan (2009) states that religion is "relies on material means" such as clothing, space, and artifacts that create a shared identity and a 'social body.' The social body that Morgan refers to is "an imagined, felt association to which the individual belongs and in which she experiences her connection in a variety of sensuous ways" and "a larger whole intuited by feeling, sensation, and imagination" (Morgan, 2009). On the other hand, religious material objects such as pictures, dances, songs, rooms, congregational meetings mediate this social body.

The wearing of special clothes in prayer experienced by the beginners of Syahadatain presents a different experience. They felt being alienated from the community and being recognised in a new way. There are two sensations experienced by them when wearing white turban robes: when they gather with the Syahadatain congregation and when they pray together in the mosque of the general public.

When they gather with the Syahadatain congregation, they felt participating in expanded collective reality with material similarity in dress and practice the same rituals such as tawassul and marhabaan. Collective experiences in groups that have the same material images and carry out rituals together calibrate feelings and emotions as social media related to events, rituals, places, objects, clothes, food, songs, music, movements, or totem figures experienced in general. The artifact of special prayer clothing that they experienced becomes a social media that educates the senses of the beginners and operates as a form of sociality. The feelings generated by these practices influence social cohesion, group identity, communal relations, and the coercive power of social participation. In contrast, when wearing special clothes outside the Syahadatain group, they felt alienated and thrown away. Their particular clothes make them not part of the general congregation of prayers. Fortunately, outside of prayer times, they wear the same clothes as other societies in general. Thus, they remain part of the community.

Special clothing in prayer makes religion become a lived religion in two worlds. When performing rituals and praying five times, the practice of wearing special prayer clothes makes them part of the special community of the Syahadatain congregation and the spiritual community of the guardians and prophets. Meanwhile, in everyday life with the same clothes as the society in general, they become part of the social body in general. It becomes a separation between the two ritual worlds and the social world. However, their attached social views make them compelled to improve their social behaviour. The social view that remains attached to the "difference of clothing during prayer" makes them feel like they are wearing prayer clothes imaginary. Here, there is a negotiation between being a part of the body of the spiritual group and the social body of society in general.

Third, the power of material culture lies in its ability to physically present what is distant or nonexistent, or unreasonable. Material culture can also embody unclear feelings, dim hunches, distant pasts, deceased leaders or saints, religious communities, intangible or transcendent realities.

Special dress in prayer imposed on beginners Syahadatain can present a reflection of a special meeting between the believers and their Lord. Prayer that was originally just a ritual habit turned into a special activity that must be prepared. At the same time, these special garments make them feel part of a larger community of spirituality, prophets, and guardians. It is a sensation that makes them feel special.

The material culture in religion also demonstrates its ability to discipline and engage the body of the practitioners in an act of shared imagination. Clothing not only constructs the body but also encourages the practitioners to manage their time, space, purpose, and collective identity. When they differ in prayer dress, they find themselves new who do a new pattern of behaviour.

"This robe makes me feel watched over and encourages me to learn again" is a statement that shows the influence of fashion specifically in behaviour formation. The driving factor is the social assessment of the symbol of robes as ulama have. The image of ulama who are already seriously religious makes new members encouraged to complete themselves with moral behaviour. This phenomenon is almost similar to Asad and Mahmood which shows that the habitus actors changed themselves driven by the agency of tradition embodied, not by themselves (Mahmood, 2012). Nevertheless, this phenomenon shows another finding that changes appearance not only because of 
the tradition of teaching but the eyes gaze of people who have a social imagination that wearing a robe means religious figures.

\section{Conclusion}

Religion or spirituality cannot be separated from material objects. This research on beginners in the Syahadatain congregation Cirebon shows the strength of special clothing material objects in prayer in the formation of religious experiences. Due to discursive awareness on verbal beliefs and knowledge and non-discursive on material matters in religion, religion still requires non-discursive awareness. It is different from the modern belief which states that rituals and material objects do not affect life. Modern belief considers that moral behaviour only arises from considerations of praxis ratio as stated by Immanuel Kant. This study also shows the different findings from Asad and Mahmood's studies. The emergence of determinants of habitus is social gaze, not traditional structures as the driving force for moral behaviour formation. On the other hand, this study reinforces what David Morgan built that material culture is the framework in which the world of thoughts and feelings of religious life is formed. Thoughts, feelings, practices, objects complement one another in constructing the spiritual experience. It means that the study of material artifacts such as clothing can be an alternative to the study of religion in Indonesia.

This study with embodiment theory and discursive-praxis awareness can explain the relationship between the material aspects of religion (special fashion in rituals) and religious studies. If previous consideration states that material things in religion only become attributes that are not related to strengthening religious discursive awareness, the finding of this study can show that non-discursive awareness strengthens discursive awareness. Even the non-discursive awareness is constructed from the embodiment of material aspects of religion.

This study has two limitations: the limited research subjects that only involve new members of the Syahadatain congregation and the limited material object that only focuses on special fashion in prayer. This study needs expanded research subjects namely entire members of Syahadatain congregation or members of other Sufi orders in general who wear special fashions in prayer. Meanwhile, the findings of the influence of social gaze on habitus behaviour need further research on religious adherents who wear other special fashions (hijab, niqab, koko shirt) in public spaces.

\section{References}

Al-`Asqalānī, A. ibn ‘Alīi ibn Ḥajar. (2005). Fath al-Bārī Sharh Șahịḥh al- Bukhārī. Riyāụ: Dār Ṭībah.

Al-Bakri, S. A. B. (1997). I'anatuth Thâlibin. Beirut: Dârul Fikr.

Al-Hishni, T. A. B. bin M. (2001). Kifayatu Al-Akhyar Fi Halli Ghoyati Al-Ikhtishor. Beirut: Dār al-Kutub al-'Ilmiyyah. Appadurai, A. (1986). The Social Life of Things. Commodities in Cultural Perspective. New York: Cambridge University Press.

Asad, T. (1983). Anthropological Conceptions of Religion: Reflections on Geertz. Man, 18(2), 237-259. https://doi.org/10.2307/2801433

Asad, T. (1993). Genealogies of Religion: Discipline and Reasons of Power in Christianity and Islam. Baltimore: Johns Hopkins University Press.

Asad, T. (2001). Reading a Modern Classic: W. C. Smith's ‘The Meaning and End of Religion'. History of Religions, 40(3), 205-222. https://doi.org/10.1086/463633

Bell, C. (1992). Ritual Theory, Ritual Practice. New York - Oxford: Oxford University Press.

Bourdieu, P. (1990). The Logic of Practice. Cambridge: Polity.

Brekhus, W. (2015). Culture and Cognition: Patterns in the Social Construction of Reality. Cambridge: Polity Press.

Cerulo, K. A. (2010). Mining the intersections of cognitive sociology and neuroscience. Poetics, 38(2), 115-132. https://doi.org/10.1016/j.poetic.2009.11.005

Elias, J. J. (2012). Aisha's Cushion: Religious Art, Perception, and Practice in Islam. Cambridge, MA and London, England: Harvard University Press. https://doi.org/10.4159/harvard.9780674067394

Engelke, M. (2011). Material religion. In The Cambridge Companion to Religious Studies (pp. 209-229). Cambridge: Cambridge University Press. https://doi.org/10.1017/CCOL9780521883917.012

Entwistle, J. (2000). Fashion and the Fleshy Body: Dress as Embodied Practice. Fashion Theory, 4(3), 323-347. https://doi.org/10.2752/136270400778995471 
Entwistle, J. (2001). Body Dressing. London: Berg.

Entwistle, J. (2015). The Fashioned Body; Fashion, Dress and Modern Social Theory. Cambridge: Polity.

Foucault, M. (1975). The Birth of the Clinic: An Archaeology of Medical Perception. New York: Vintage Books.

Foucault, M. (1977). Discipline and Punish. Harmondsworth: Penguin.

Foucault, M. (1980). Body/Power. In C. Gordon (Ed.), Power/Knowledge: Selected Interviews and Other Writings 197277. New York: Pantheon Books.

Geertz, C. (1973). The Interpretation of Cultures. New York: Basic Books.

Goffman, E. (1971). The Presentation of the Self in Everyday Life. Harmondsworth: Penguin.

Hazard, S. (2013). The Material Turn in the Study of Religion. Religion and Society, 4(1), 58-78. https://doi.org/10.3167/arrs.2013.040104

Hazim, N. (2016). Adillah Asy-Syahadatain. Cirebon: Pustaka Syahadat Sejati.

Hughes, J. S. (2010). Biography of a Mexican Crucifix: Lived Religion and Local Faith from the conquest to the present. Oxford: Oxford University Press.

Ignatow, G. (2007). Theories of Embodied Knowledge: New Directions for Cultural and Cognitive Sociology? Journal for the Theory of Social Behaviour, 37(2), 115-135. https://doi.org/10.1111/j.1468-5914.2007.00328.x

Kant, I. (1993). Grounding for the Metaphysics of Morals; with, On a Supposed Right to Lie because of Philanthropic Concerns (J. W. Ellington, ed.). Indianapolis: Hackett Pub. Co.

Laban, R. (1980). The Mastery of Movement. Plymouth, United Kingdom: Northcote House.

Lambek, M. (2014). What is 'religion' for anthropology? And what has anthropology brought to 'religion'. In J. Boddy \& M. Lambek (Eds.), A Companion to the Anthropology of Religion. Oxford: Wiley.

Latour, B. (2010). On the Modern Cult of the Factish Gods. Durham: Duke University Press.

Mahmood, S. (2012). Politics of Piety: The Islamic Revival and the Feminist Subject. Princeton - New Jersey: Princeton University Press.

Mastuki, H., \& El-Saha, M. I. (2003). Intelektualisme Pesantren Potret Tokoh dan Cakrawala Pemikiran di Era Keemasan Pesantren. Jakarta: Diva Pustaka.

Mauss, M. (1973). Techniques of the body. Economy and Society, 2(1), $70-88$. https://doi.org/10.1080/03085147300000003

Merleau-Ponty, M. (1962). The Phenomenology of Perception. London: Routledge.

Meyer, B. (2011). Mediation and immediacy: sensational forms, semiotic ideologies and the question of the medium. Social Anthropology, 19(1), 23-39. https://doi.org/10.1111/j.1469-8676.2010.00137.x

Morgan, D. (2009). The Material Culture of Lived Religion: Visuality and Embodiment. Conference for Art Historians, Studies in Art History, 15-31.

Morgan, D. (2010). Religion and Material Culture: The Matter of Belief. London: Routledge.

Negrin, L. (2012a). Aesthetics: Fashion and Aesthetics - a fraught relationship. In A. Geczy \& V. Karaminas (Eds.), Fashion and Art (pp. 43-54). London: Berg.

Negrin, L. (2012b). Fashion as an Embodied Art Form. In B. Bolt \& E. Barrett (Eds.), Carnal Knowledge towards a 'New Materialism' through the Arts. London and New Yor: I.B.Tauris \& Co Ltd.

Negrin, L. (2016). Maurice Merleau-Ponty: The Corporeal Experience of Fashion. In A. Rocamora \& A. Smelik (Eds.), Thinking through Fashion: A Guide to the Key Theorists. New York: I.B. Taurus.

Nuroniyah, W. (2019). Rethinking Hijab in Contemporary Indonesia: A Study of Hijab Community “Tuneeca Lover Community". Wawasan: Jurnal Ilmiah Agama Dan Sosial Budaya, 4(2), $214-221$. https://doi.org/10.15575/jw.v4i2.5643

Ochoa, T. R. (2010). Society of the Dead: Quita Manaquita and Palo Praise in Cuba. Berkeley: University of California Press. https://doi.org/10.1525/9780520947924

Promey, S. M., \& Brisman, S. (2010). Sensory Cultures: Material and Visual Religion Reconsidered. In The Blackwell Companion to Religion in America (pp. 177-205). Oxford, UK: Wiley-Blackwell. https://doi.org/10.1002/9781444324082.ch13

Turner, B. S., \& Asad, T. (1994). Genealogies of Religion: Discipline and Reasons of Power in Christianity and Islam. Sociology of Religion, 55(3), 371-373. https://doi.org/10.2307/3712068

Vaisey, S. (2008). Socrates, Skinner, and Aristotle: Three Ways of Thinking About Culture in Action 1. Sociological Forum, 23(3), 603-613. https://doi.org/10.1111/j.1573-7861.2008.00079.x

Vaisey, S. (2009). Motivation and Justification: A Dual-Process Model of Culture in Action. American Journal of Sociology, 114(6), 1675-1715. https://doi.org/10.1086/597179

Vásquez, M. (2010). More Than Belief: A Materialist Theory of Religion. New York: Oxford University Press.

Winchester, D. (2008). Embodying the Faith: Religious Practice and the Making of a Muslim Moral Habitus. Social Forces, 86(4), 1753-1780. https://doi.org/10.1353/sof.0.0038

Winchester, D. (2017). "A Part of Who I Am": Material Objects as "Plot Devices" in the Formation of Religious 
Selves. Journal for the Scientific Study of Religion, 56(1), 83-103. https://doi.org/10.1111/jssr.12318

Winchester, D., \& Guhin, J. (2019). Praying "Straight from the Heart": Evangelical sincerity and the normative frames of culture in action. Poetics, 72, 32-42. https://doi.org/10.1016/j.poetic.2018.10.003

Woodward, S. (2007). Why Women Wear What They Wear. Oxford: Berg.

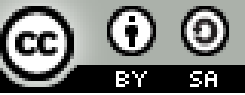

(C) 2021 by the authors. Submitted for possible open access publication under the terms and conditions of the Creative Commons Attribution (CC BY SA) license (https://creativecommons.org/licenses/by-sa/3.0/). 